\title{
Molai Aadu Goat Warrant Immediate Registration and Conservation
}

\author{
T. Ravimurugan ${ }^{*}$ and A. Kirubakaran ${ }^{2}$ \\ ${ }^{1}$ Department of Animal Genetics and Breeding, Veterinary College and Research Institute, \\ Ramayanpatti - 627 358, Tirunelveli, India \\ ${ }^{2}$ Veterinary University Training and Research Institute, Erode \\ Tamil Nadu Veterinary and Animal Sciences University, India \\ *Corresponding author
}

\section{A B S T R A C T}

Molai aadu is a lesser known goat breed rearing for meat purpose in Tamil Nadu and not yet registered as distinct breed. So far no sincere efforts have been made for registration of this population of important genotype. Hence, the present study was carried out to document Molai Aadu goat by using the proforma developed by the NBAGR, Karnal.

\section{Keywords}

Goat, Molai aadu, Tamil Nadu

Article Info

Accepted:

12 December 2018

Available Online:

10 January 2019 Molai aadu goat is very popular among the breeders and has spread to Salem, Namakkal, Karur, Erode and Tirupur districts. The goat is prevalently spread to Chithode, Kavundapadi, Sirivaloor, Nambiyoor, Kanjikovil and Nallampatty areas of Erode district. The Molai Aadu goat is moderate in size with musculature. The colour of the animal mostly white in colour sometimes varies from complete white to light brown shades. The average body weights in males at birth, 3month, 6month, 9month, 12 month and two-four tooth age groups were found as $2.05,7.50,12.45,15.0,17.75$ and $29.15 \mathrm{~kg}$, respectively. The corresponding values for females were $1.85,6.70,10.50,13.5,16.0$ and $26.35 \mathrm{~kg}$, respectively. The average reproductive performance viz. age at first kidding, kidding interval and gestation length were observed as 14.45 months (Range 14-20 months), 8.14 months (Range 6-9 months) and 147.81 days (Range 145-151 days), respectively. About 32 per cent does have a tendency of giving birth to twins. The goat had good reproductive ability and recorded litter size with maximum of six kids. In situ conservation of the breed and establishment of elite nucleus herds in the Government farms may be undertaken.

\section{Introduction}

Tamil Nadu is one of the states in India, where goat is an important livestock species of oppressed people and contributes substantially to the livelihood of the farmers especially the small and landless labourers. The goat population of Tamil Nadu state has decreased by 12.20 per cent between $18^{\text {th }}$ Livestock census, 2007 (8143341) and $19^{\text {th }}$ Livestock census, 2012 (9274584). Apart from a registered breed of goat Kanni aadu, Kodi aadu and Salem Black, there are several lesser known population viz., Pallai Aadu and Molai Aadu goat in this state, not yet registered. These goat breeds have been developed through natural selection to adapt to particular agro-climatic conditions. Molai aadu goat is 
one of such rare breed with greater recognition as a meat breed due to prolificacy, reproductive efficiency and sufficient milk to nourish high litter sizes. So far no sincere efforts have been made for registration of this population of important genotype. Hence, the present study was carried out to document Molai Aadu goat by using the proforma developed by the NBAGR, Karnal.

\section{Materials and Methods}

During 2018, a survey was carried in western districts of Tamil Nadu for characterization of Molai aadu goat and the husbandry practices adopted by the farmers.

The habitat and distribution of Molai aadu goat was ascertained by visiting Modachur and Mylambadi weekly sandy's of Erode district. Body measurements $(\mathrm{cm})$ and body weight $(\mathrm{kg})$ of the adult goat was recorded in Thingaloor, and Nallampatty of Perundurai block; Chithode and Kanjikovil of Erode Taluk, Nambiyoor and Gobichettipalayam of Gobichettipalayam Taluk; Sathyamangalam of Sathyamangalam Taluk of Erode district (11.5246 $\mathrm{N}$ latitude and $77.4702^{\circ} \mathrm{E}$ longitude and $160 \mathrm{M}$ above M.S.L) of Tamil Nadu. The following physical traits were measured as per the procedure given by Singh et al., (1979) and Sasimowski (1987).

Height at withers: vertical distance between ground and point at withers.

Body length: distance between the anterior edge of the shoulder joint and posterior end of the point of buttock.

Chest girth: smallest circumference of the body immediately behind the shoulder.

Ear length: distance between the base and tip of the pinna.

Tail length: distance covered from the base to the tip of the tail.

Face length: length of face from occipital crest to upper edge of the muzzle.
The data recorded were scrutinised, edited and collated. As the data were unequal and disproportionate in different subclasses, leastsquares analysis (Harvey, 1990) was performed. Duncan's Multiple Range Test (DMRT) was applied (Kramer, 1957) whenever the effect was significant and the subclasses were more than two.

\section{Results and Discussion}

Molai aadu goat is very popular among the breeders and has spread to Salem, Namakkal, Karur, Erode and Tirupur districts. The goat is prevalently spread to Chithode, Kavundapadi, Sirivaloor, Nambiyoor, Kanjikovil and Nallampatty areas of Erode district. Erode District is situated between $1036^{\prime \prime}$ and 11 58" north latitude and between 76 49" and 77 58" east longitude.

The region of Molai aadu goat tract comprises, Perundurai, Erode and Gobichettipalayam Taluk has dry weather throughout the year, except monsoon season. The temperature slowly rises during March month and reaches highest in May month. Pleasant environment observed during September month. Northeast monsoon sets during October-November month. Soils of Bhavani, Erode and Perundurai taluks are gravelly, stony and sandy of the red variety. Soils of Gobichettipalayam and Sathyamangalam taluks are mostly of the red sandy variety. Red loam is prevalent mostly in Gobichettipalayam and Perundurai taluks.

The goats are maintained on semi-intensive management and found that it is mixed with local goat of different colour. The herd size with a farmer varied from 2 to 10 . The population of this breed was estimated to be 5000. The Molai Aadu goat is moderate in size with musculature. The colour of the animal mostly is white sometimes varies from complete white to light brown shades. All 
goats had black coloured muzzle with irregular black patches. Hooves were generally light brown in colour. Ears were semi pendulous with average length of $14.5 \pm$ $0.5 \mathrm{~cm}$. The forehead was straight in nature. Both sexes were not horned that is the reason it is called as Molai Aadu (Fig. 1 and 2). "Molai means hornless in Tamil. Wattle and beard were absent. All does had bowl shape udder with cylindrical teats having blunted tip. The average body weights in males at birth, 3 month, 6month, 9month, 12month and twofour tooth age groups were found as 2.05, $7.50,12.45,15.0,17.75$ and $29.15 \mathrm{~kg}$, respectively. The corresponding values for females were $1.85,6.70,10.50,13.5,16.0$ and $26.35 \mathrm{~kg}$, respectively. The means for height at withers, chest girth, body length and tail length were $78.5,74.0,56.5$ and $14.5 \mathrm{~cm}$, respectively in males and 70.5, 69.0, 53.5 and $15.0 \mathrm{~cm}$, respectively in females. The body length was short. Males had slightly higher values than females for all three principal measurements. Body measurements observed in Molai aadu were lower than Kodi Aadu (Mariadas, 1996; Jain et al., 2000) and higher than Pallai adu (Ravimurugan et al., 2009).

The average reproductive performance viz. age at first kidding, kidding interval and gestation length were observed as 14.45 months (Range 14-20 months), 8.14 months (Range 6-9 months) and 147.81 days (Range 145-151 days), respectively.

Fig.1 Molai aadu - Buck

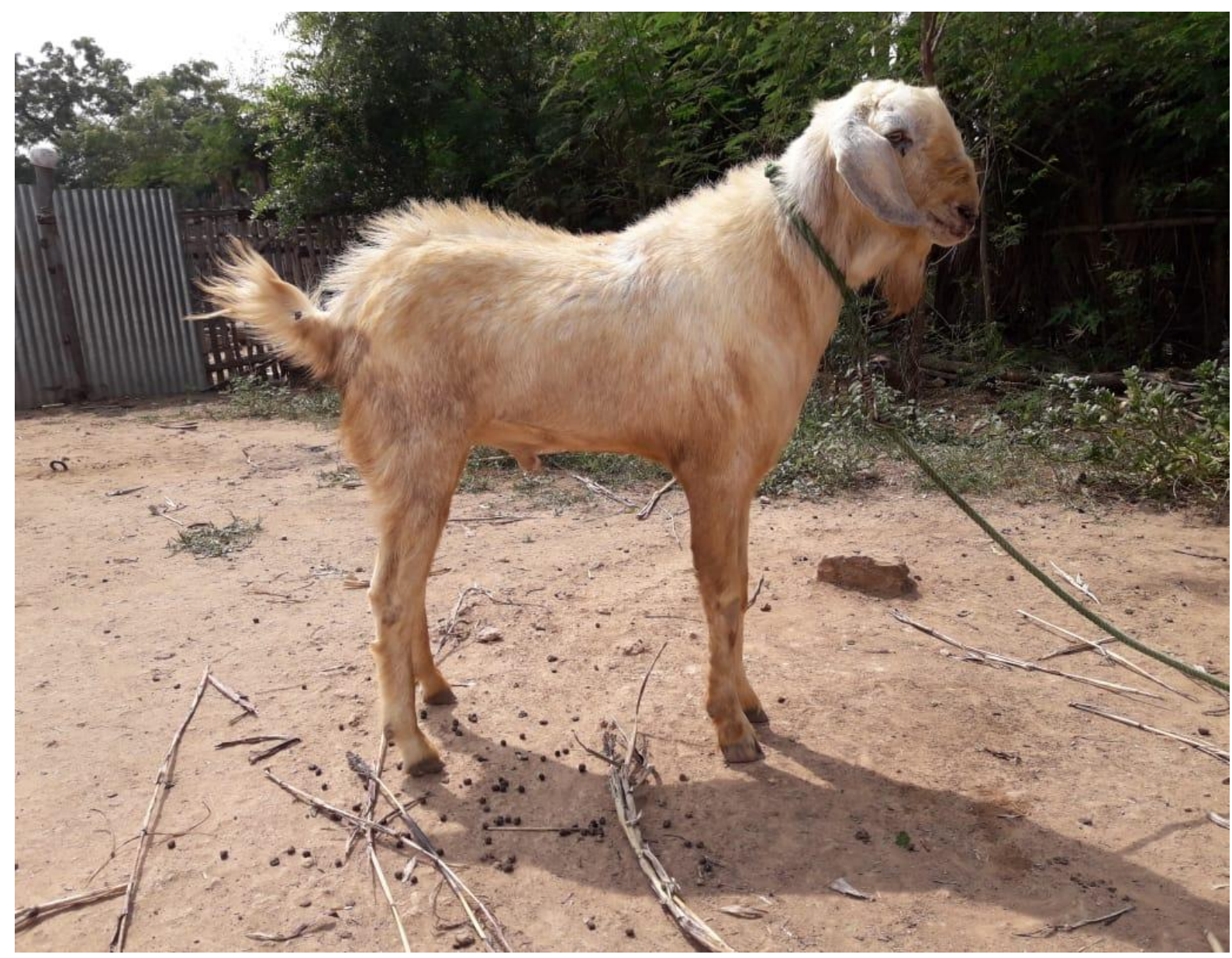


Fig.2 Molai aadu - Doe

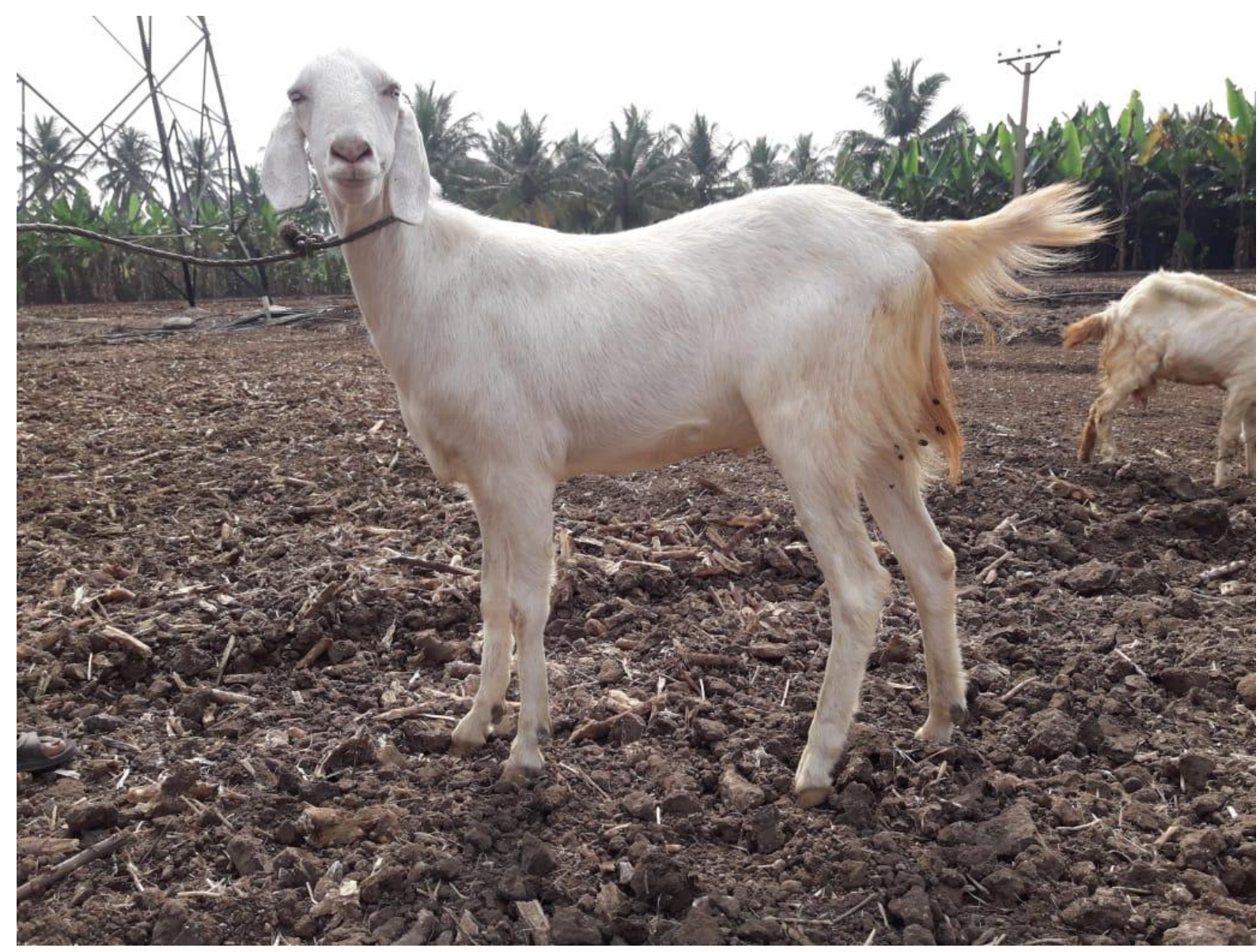

Female born as single birth matured faster and kidded at two years of age, whereas, twin born females matured comparatively slowly and kidded two months late indicating that single birth kids might have higher reproductive efficiency trait. The age at first kidding observed in Molai Aadu goat is comparable (14.63 months) for Kanni Aadu, which is another native breed of Tamil Nadu (Report, 2003). About 32 per cent does have a tendency of giving birth to twins. The goat had good reproductive ability and recorded litter size with maximum of six kids.

Molai aadu goat serves as the sole or subsidiary source of livelihood for a large number of small and marginal farmers in the breeding tract. They provide income, employment opportunity and food security to the farmers in Western districts of Tamil Nadu. In situ conservation of the breed and establishment of elite nucleus herds in the Government farms may be undertaken.

\section{References}

Jain, A., Sahana, G., Kandasamy, N. and Nivsarkar, N. E. (2000). Kodi Aadu- A new goat breed of Tamil Nadu. Indian J.Anim.Sci.,70:649-651.

Harvey, W. R. (1990). User guide for LSMLMW and MIXMDL PC@ version mixed model least-squares and maximum likelihood computer programme. Ohio State University, Columbas, Ohio, U.S.A.

Kramer, C. Y. (1957). Extension of multiple range tests to group correlated adjusted 
means. Biometrics, 13:13-18.

Mariadas, B. (1996). Goat breeds of Tamil Nadu (Tamil Nattin Velladu Inangal). Monograph, pp.13.

Ravimurugan, T., Devendran, P., Cauveri, D. and Balachandran, S. (2009). Performance of Indigenous goat (Pallai Adu) under field conditions. Tamil Nadu J. Vet \& Anim. Sci., 5(5): 203207.

Report, (2003). Annual Report 2002-2003.
National Bureau of Animal Genetic Resources, Karnal.

Sasimowski, E. (1987). Animal Breeding and Production on Outline. Elsevier, Amsterdam, pp.31-113.

Singh, C.S.P., Mishra, H. R., Sharma, B. D., Mukherjee, D. K. and Singh, D. K. (1979). A note on body measurements of Black Bengal goats. J. Anim. Sci., 49:669-671.

\section{How to cite this article:}

Ravimurugan, T. and Kirubakaran, A. 2019. Molai Aadu Goat Warrant Immediate Registration and Conservation. Int.J.Curr.Microbiol.App.Sci. 8(01): 1755-1759.

doi: https://doi.org/10.20546/ijcmas.2019.801.186 